\title{
Remote Sensing for Characterisation and Kinematic Analysis of Large Slope Failures: Debre Sina Landslide, Main Ethiopian Rift Escarpment
}

\author{
Jan Kropáček ${ }^{1, *}$, Zuzana Vařilová ${ }^{2,3}$, Ivo Baroň ${ }^{4}$, Atanu Bhattacharya ${ }^{5}$, Joachim Eberle ${ }^{1}$ \\ and Volker Hochschild ${ }^{1}$ \\ Received: 10 July 2015; Accepted: 19 November 2015; Published: 2 December 2015 \\ Academic Editors: Zhenhong Li, Roberto Tomas, Richard Gloaguen and Prasad S. Thenkabail \\ 1 Department of Geosciences, University of Tuebingen, Rümelinstr. 19-23, 72070 Tübingen, Germany; \\ joachim.eberle@uni-tuebingen.de (J.E.); volker.hochschild@uni-tuebingen.de (V.H.) \\ 2 Municipal Museum of Ústí nad Labem, Masarykova 1000/3, 40001 Ústí nad Labem, Czech Republic; \\ varilova@muzeumusti.cz \\ 3 Geo-Tools, U Mlejnku 128, Přemyšlení, 25066 Zdiby, Czech Republic \\ 4 Department of Geology and Paleontology, Natural History Museum Vienna, Burgring 7, 1010 Vienna, \\ Austria; Ivo.Baron@nhm-wien.ac.at \\ 5 Institute for Cartography, TU Dresden, Helmholzstr. 10, 01062 Dresden, Germany; atanudeq@gmail.com \\ * Correspondence: jan.kropacek@uni-tuebingen.de; Tel.: +49-7071-297-8940; Fax: +491-7071-295-378
}

\begin{abstract}
Frequently occurring landslides in Ethiopia endanger rapidly expanding settlements and infrastructure. We investigated a large landslide on the western escarpment of the Main Ethiopian Rift close to Debre Sina. To understand the extent and amplitude of the movements, we derived vectors of horizontal displacements by feature matching of very high resolution satellite images (VHR). The major movements occurred in two phases, after the rainy seasons in 2005 and 2006 reaching magnitudes of $48 \pm 10.1 \mathrm{~m}$ and $114 \pm 7.2 \mathrm{~m}$, respectively. The results for the first phase were supported by amplitude tracking using two Envisat/ASAR scenes from the 31 July 2004 and the 29 October 2005. Surface changes in vertical direction were analyzed by subtraction of a pre-event digital elevation model (DEM) from aerial photographs and post-event DEM from ALOS/PRISM triplet data. Furthermore, we derived elevation changes using satellite laser altimetry measurement acquired by the ICESat satellite. These analyses allowed us to delineate the main landslide, which covers an area of $6.5 \mathrm{~km}^{2}$, shallow landslides surrounding the main landslide body that increased the area to $8.5 \mathrm{~km}^{2}$, and the stable area in the lower part of the slope. We assume that the main triggering factor for such a large landslide was precipitation cumulated over several months and we suspect that the slope failure will progress towards the foot of the slope.
\end{abstract}

Keywords: Ethiopian rift; Tarmaber area; Debre Sina; large landslide; feature tracking; amplitude tracking; DEM differencing; ICESat

\section{Introduction}

Deformation of the Earth's surface caused by various geodynamic processes represents a serious hazard for settlements and infrastructure. In the last few decades, remote-sensing techniques have proven to be an effective tool to identify and monitor surface deformations of glaciers, permafrost and landslides. Correlation techniques of consecutive optical space-borne images results in displacement vector fields, which provide valuable information on the character of the movement [1-3]. These techniques are based on image windows correlation in space domain [4] or frequency domain $[5,6]$. The accuracy of these approaches is by the rule of thumb on order of pixel size of the correlated image data [2]. However, recent studies have shown that an accuracy of one-fourth to one-fifth of a 
pixel size can be achieved provided VHR stereo pairs are available [7,8]. Furthermore, Differential SAR interferometry (DInSAR) techniques were successfully used for investigation of landslides, e.g., [9-11]. The use of this technique is, however, limited by temporal decorrelation, terrain setting and orientation and by relation of the movement velocity to the used radar frequency [12]. Amplitude tracking is another technique for movement detection based on SAR (Synthetic Aperture Radar) data. Unlike DInSAR it is based purely on the amplitude information. This technique is often used for glacier monitoring [13-15]. In this approach, the movement velocities can be measured independently from the movement direction with respect to the range direction and additionally, the coherence of the image pair is not required [13]. A time series of DEMs extracted form historical photographs were used to capture morphological change caused by a landslide by $[16,17]$. The difficulties caused by the limited ground control and missing camera calibration protocol can be solved by the application of self-calibrating bundle adjustment methods [17]. It was demonstrated by [18] that DEM differencing using DEMs derived from VHR satellite data can be effectively used to investigate mass displacement of large landslides. This technique is also effective for a delineation of large landslides [18].

Slopes of the Ethiopian Highlands are frequently affected by landslides of various types, which often lead to eviction of inhabitants, damage to housing, infrastructure and arable land and even loss of human lives $[19,20]$. Most of the landslides in this region, including the largest ones, are triggered by heavy precipitation occurring at the end of the rainy periods in July and August [21], whereas earthquakes mainly trigger fast moving slope failures such as rock slides, topples and falls [19]. An extraordinarily large slope failure occurred in the Yizaba locality of the Tarmaber area north of the town of Debre Sina (Figure 1). The landslide has been studied by [22] who mapped susceptibility zones, analyzed precipitation, described basic geological site settings and pointed out earthquakes in Afar Rift as the probably main triggering factor. Field hydro-geological investigations and geophysical sounding were reported by [23]. There are some substantial discrepancies in the reported extent and evolution of the Debre Sina landslide. Several opinions regarding the dating of the major sliding phases can be found in literature. The occurrence of the first cracks was dated as 21 August 2005 by [24], while [25] reports September 2005. Based on eyewitness accounts, [23] states that the formation of tension cracks had already occurred in August 2004. The major sliding event was dated as 13-14 September 2005 by the report of Action by Churches released in 2006 (in [22,26]). This is in accordance to [24] who reports 13 September 2005, while September 2006 is reported by [24,25]. We suppose that the major movements occurred in two phases as [23] reports two major movements in September 2005 and in September 2006 based on interviews with local inhabitants.

In this study, we aim at demonstration of the potential of optical and microwave remote sensing techniques in combination with DEMs for investigation of the extent, evolution and properties of a large landslide. 


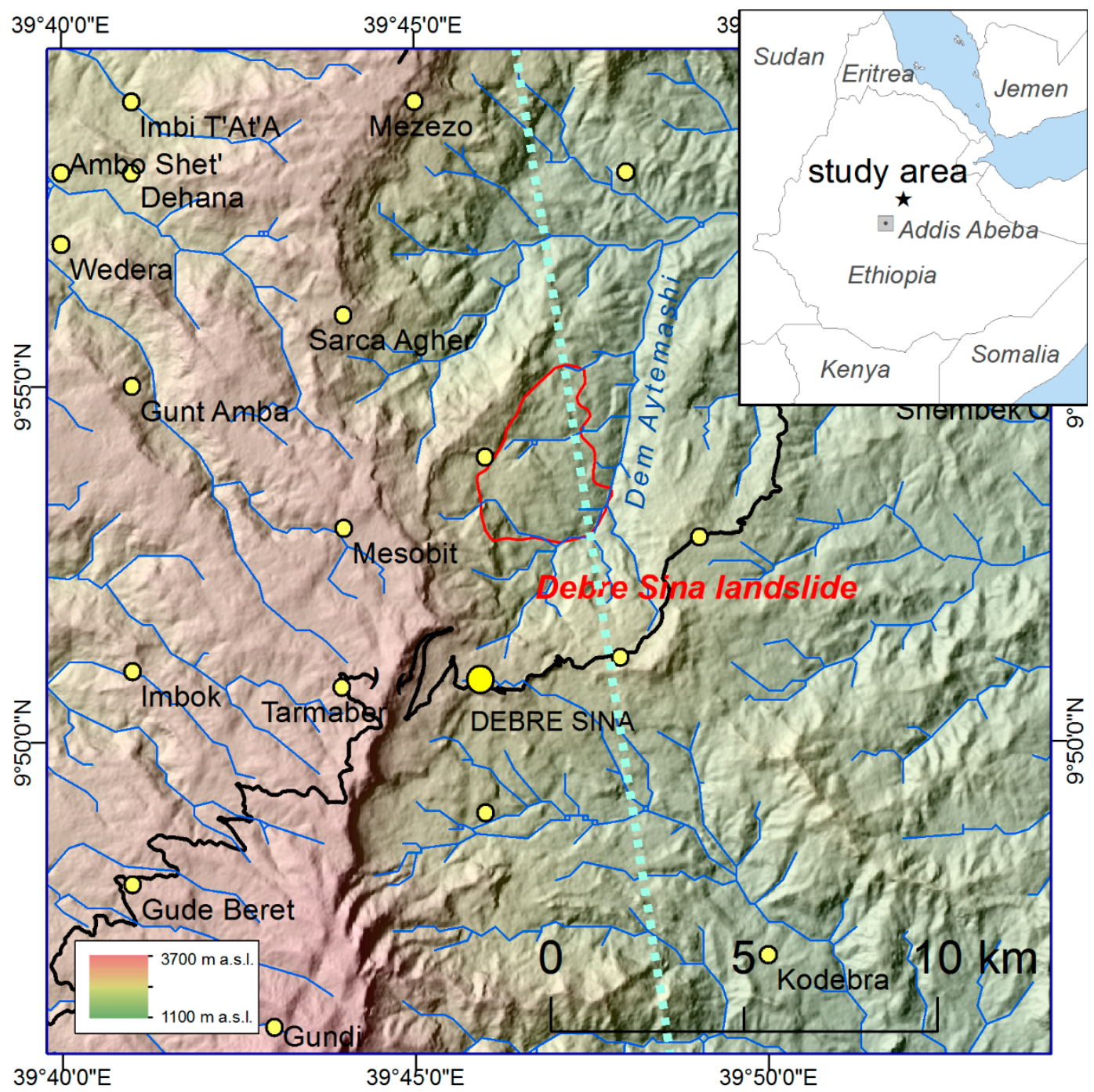

Figure 1. The study area is located on the western escarpment of the Main Ethiopian Rift close to the trunk road that connects Addis Ababa with the northern regions of the country. The nominal ground track of ICESat is shown as a light blue dotted line.

\section{Study Area}

The Debre Sina landslide is located on the western escarpment of the Main Ethiopian Rift (MER) (Figure 1). The rift escarpment is formed by sequences of tertiary volcanic rock formations. The study area is characterized by rugged relief, with rock outcrops, deeply dissected creeks and channels but also by less steep areas with terraced arable land (Figure 2). 

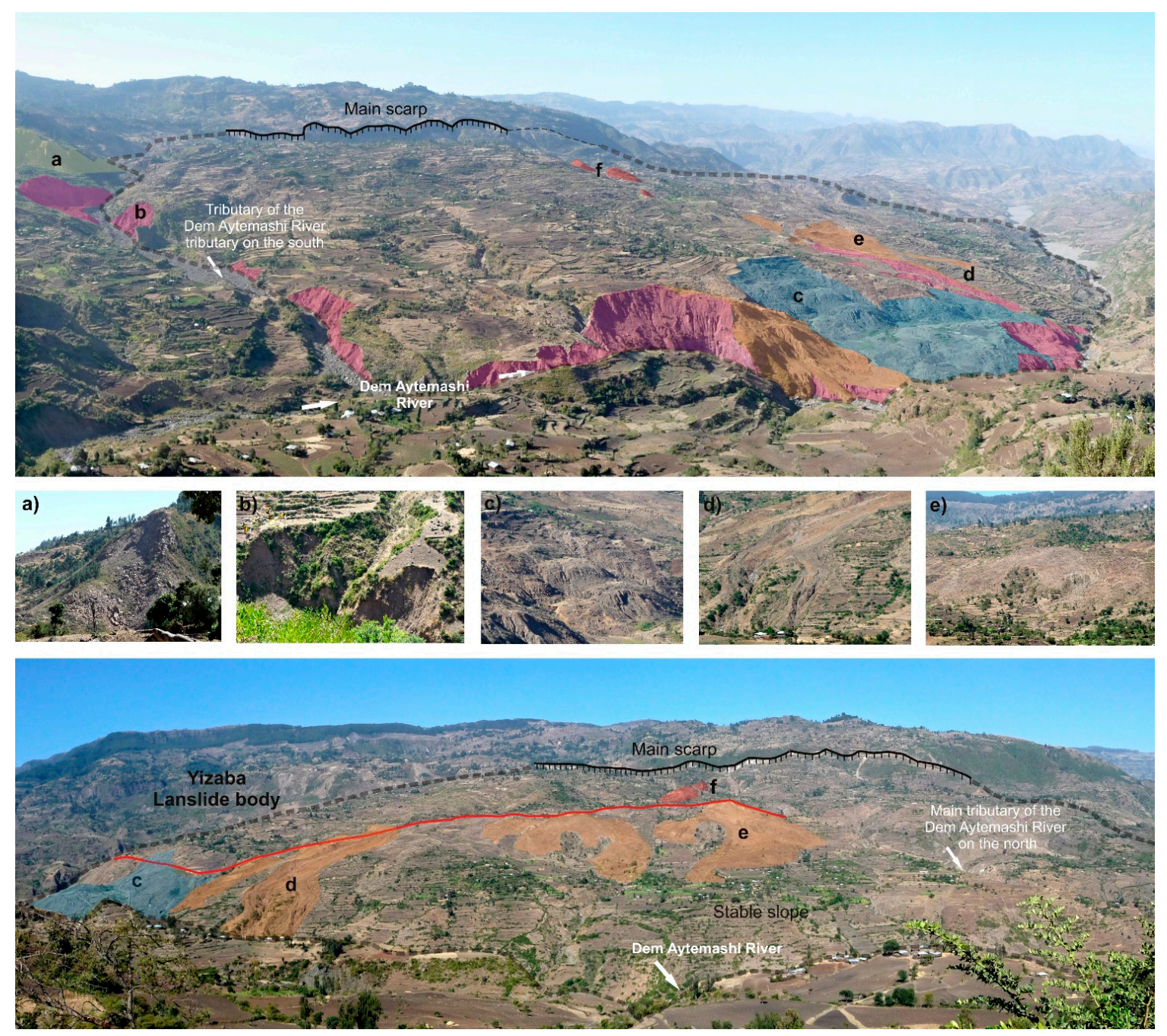

Figure 2. Panoramic view of the Debre Sina landslide from the SE (above) and E (below) with examples of characteristic geodynamic features within the main landslide body and its close surroundings: rockfalls (a); gully erosion along the Dem Aytemashi River and its tributaries (b); rotational landslides (c); debris flows (d); shallow landslide and earthflow (e); and displaced rock blocks with well-marked scarp lines (f). The estimated position of the shear plane outcrop is shown as a blue line. All photos were taken in March 2015 by Zuzana Vařilová.

The bedrock in the lower part of the slope consists of alternating layers of basalt, rhyolitic or trachytic ignimbrites as well as tuffs and agglomerates of different volcanic material (Alaje formation), which is overlaid by basalts of the Tarmaber formation in the head scarp area of the Debre Sina landslide. The ignimbrites and tuffs of the Alaje formation, in particular, are highly altered and intensely weathered $[22,23]$. The slopes with lower inclination are covered by Quaternary sediments (alluvial, colluvial-eluvial deposits and residual soils). The landslide is located in a tectonically active area with an extension character [24]. The predominant direction of discontinuity (faults and lineaments) orientation is WSW-ENE (NW-SE) [23]. The major faults on the western boundary of the rift can have occasional earthquake tremors leading to activation of unstable ground [23]. The study area is located in a high seismic risk zone [27-29]. Fifteen earthquakes with magnitudes ranging from 4.1 to 5.9 were registered in the surrounding area within $200 \mathrm{~km}$ of distance since 1980, while in the relatively small area of the Affar depression, which is located $280 \mathrm{~km}$ North from the study area, 170 shakes with magnitude $>4.0$ have occurred since 2005 [30]. Historical records from the past 150 years show that no large magnitude earthquake occurred in MER [31]. The precipitation in the area follows 
the general pattern of the Ethiopian Highlands. After a long dry period the precipitation increases in March, April and May followed by the main rainy season in July, August and September. The mean annual precipitation measured in Debre Sina station for the period 1990-2013 is $1750 \mathrm{~mm}$, while the mean precipitation in the period from July to September is $1035 \mathrm{~mm}$. Due to the high elevation gradient in the study area the climate in the upper part is considerably colder and wetter [23]. The landslide area is drained by the Dem Aytemashi River towards the north and later to the east towards the Awash River. The drainage pattern of the basin probably follows tectonic predisposition.

\section{Methods}

\subsection{Estimation of Vertical Changes by Subtraction of Two DEMs}

To understand changes in mass distribution due to the land sliding pre- and post-event DEMs were compared. A cell-by-cell subtraction of post and pre-event DEMs provides a straightforward way of obtaining positive and negative elevation differences corresponding to accumulation or depletion, respectively.

As we could not find VHR satellite images older than 2005, we used aerial photographs from 1986 to build a pre-event DEM. Black and white contact copies of three photographs covering the study area were scanned at a resolution of $1025 \mathrm{dpi}$, which resulted in a ground resolution of approximately $1 \mathrm{~m}$, and were supplied on a DVD by the Ethiopian Mapping Agency. As no calibration protocol and accurate GCPs were available to allow us to calculate the internal and external orientation, we could not carry out the processing using traditional photogrammetry. Instead we used the Structure From Motion (SFM) approach [32,33] implemented in the PhotoScan v 1.0.4 software package. The acquisition geometry was reconstructed by an iterative bundle adjustment without reference to the cartographic coordinate system. The resulting point cloud was georeferenced a posteriori using 25 GCP identified in VHR imagery in Google Earth as no Differential Global Positioning System (DGPS) measurements were possible. The root mean square error (RMSE) calculated from residuals of 7 check points, also collected in the Google Earth, were 4.9, 5.5 and $10.6 \mathrm{~m}$ in $\mathrm{x}, \mathrm{y}$ and $\mathrm{z}$ directions, respectively. The advantage of this approach is that the inaccuracy of GCPs does not affect the internal geometry of the model. In the next step, the georeferenced point cloud with the mean density 0.83 points $/ \mathrm{m}^{2}$ was converted to a raster DEM with a resolution of $2.5 \mathrm{~m}$. Furthermore, an ortho-image with a resolution of $1 \mathrm{~m}$ was generated to complete the time series of VHR images with an image capturing the pre-event situation (Table 1). The high resolution pre-event DEM allowed us to analyze the morphology of the original terrain including theoretical surface runoff. We generated a Topography Wetness Index (TWI) (Figure 3) [34] representing potential infiltration, which is a relevant parameter for addressing the development of a slope failure [35,36].

To build a post-event DEM we used an image triplet acquired by the PRISM instrument carried by the Japanese satellite ALOS on 19 November 2008. This satellite was launched in 2006 and is dedicated to cartography and disaster monitoring. The triplet consists of three images taken by backward, nadir and forward pointing cameras which enable stereo-processing [37]. We processed the data using the Leica Photogrammetry Suite version 9.3. The resulting PRISM DEM has a resolution of $10 \mathrm{~m}$. The resulting RMSE on nine check points collected from Google Earth 6.1, 6.5 and $7.4 \mathrm{~m}$ in the $\mathrm{x}, \mathrm{y}$ and $\mathrm{z}$ directions, respectively. This value is, however, strongly influenced by the accuracy of the reference satellite imagery. Additionally, an ortho-image with grid spacing of $2.5 \mathrm{~m}$ was generated employing the SRTM DEM as the elevation reference. The use of the PRISM DEM led to an identical result even over the area of the landslide. We opted for the SRTM DEM as the PRISM DEM includes some artifacts in the areas of cloud cover. 
Table 1. High-resolution satellite images covering the study area. RMSE after co-registration of the orthorectified images with respect to the Ikonos-2 image from 14 December 2005.

\begin{tabular}{ccccccc}
\hline Satellite/Sensor & Acquisition Date & $\begin{array}{c}\text { Corresponding } \\
\text { Rainy Season }\end{array}$ & $\begin{array}{c}\text { Resolution } \\
\text { PAN/MS } \\
\text { (m) }\end{array}$ & $\begin{array}{c}\text { Off-Nadir } \\
\text { Angle } \\
\text { (Degrees) }\end{array}$ & $\begin{array}{c}\text { Sun } \\
\text { Elevation. } \\
\text { (Degrees) }\end{array}$ & $\begin{array}{c}\text { RMSE of } \\
\text { Co-Registration } \\
\text { (m); (No. Points) }\end{array}$ \\
\hline Air photos & 27 November 1986 & 1986 & 1.0 & - & - & $6.3 ;(16$ points $)$ \\
Ikonos-2 & 14 December 2005 & 2005 & $0.8 / 4.0$ & 17.5 & 52.0 & - \\
Ikonos-2 & 25 June 2007 & 2006 & $0.8 / 4.0$ & 10.6 & 65.9 & $0.88 ;(12$ points $)$ \\
Kompsat-2 & 27 January 2008 & 2007 & $1.0 / 4.0$ & 0.0 & & $0.67 ;(88$ points $)$ \\
WorldView-1 & 22 December 2008 & 2008 & 0.5 & 19.5 & 51.7 & $1.60 ;(123$ points $)$ \\
QuickBird-2 & 18 May 2010 & 2009 & 0.6 & 10.2 & 66.7 & $1.90 ;(62$ points) \\
GeoEye & 25 November 2012 & 2012 & 0.46 & 20.4 & 54.9 & $1.94 ;(143$ points $)$ \\
WorldView-2 & 27 May 2014 & 2013 & $0.46 / 1.84$ & 9.6 & 69.5 & $1.75 ;(31$ points $)$ \\
\hline
\end{tabular}

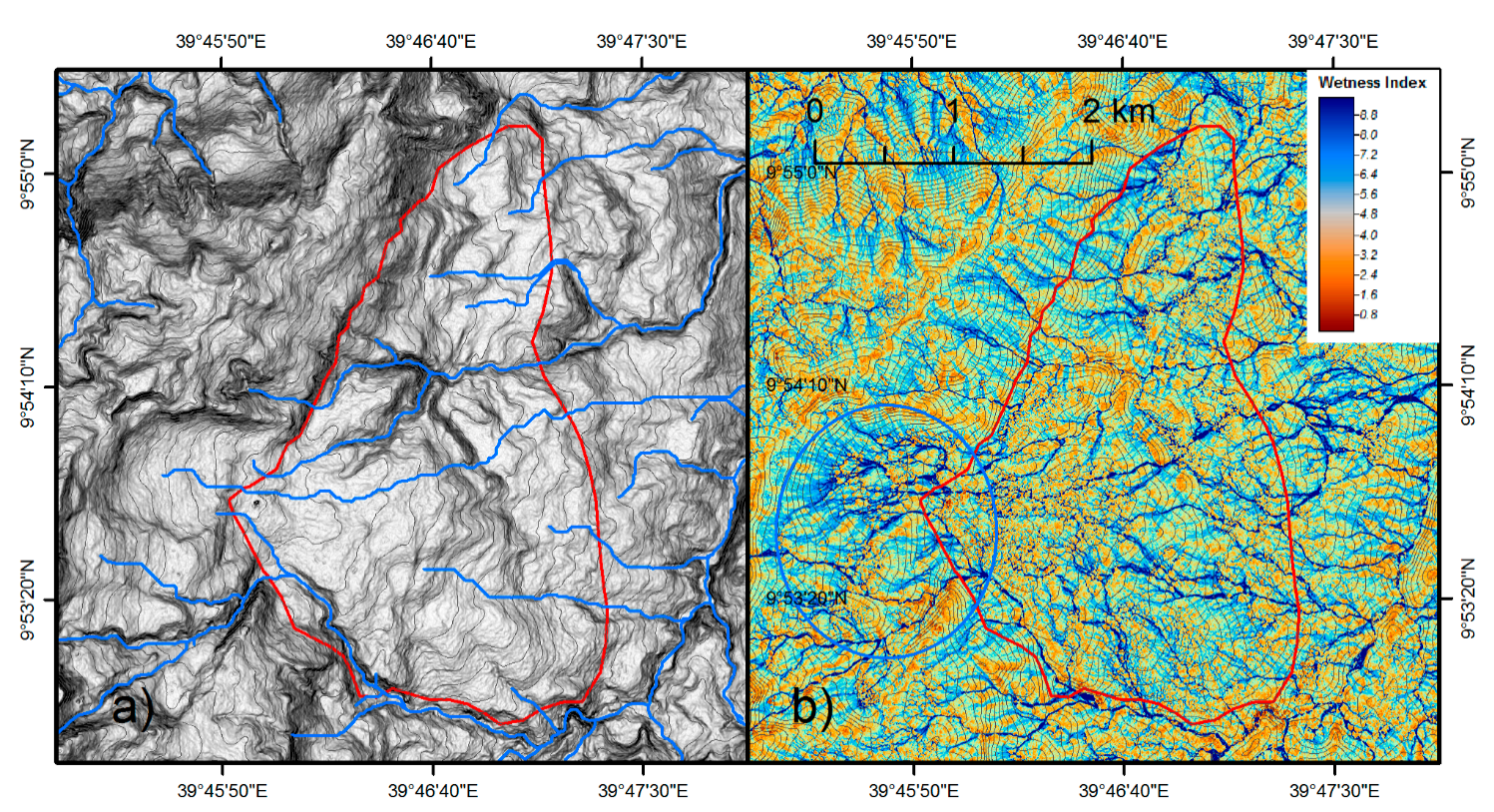

Figure 3. The pre-event DEM extracted from aerial photographs is shown as a slope inclination image overlaid with drainage (a); Topographic Wetness Index derived from the pre-event DEM shows large zones of potential infiltration above the southern part of the landslide, marked by the blue ellipse (b). The contour of the active main landslide body is in red.

The two models were accurately co-registered in a horizontal direction using piecewise linear transformation in AutosSync Workstation. In this approach, the triangular areas between the tie points are fitted using the first order polynomial. The RMSE of the co-registration in horizontal direction calculated from residuals on the used tie points was $4.6 \mathrm{~m}$. This figure indicates the amount of the residual discrepancy in horizontal direction between the two DEMs. The uncertainty of the DEM differencing was assessed as the RMSE of vertical differences on 43 randomly spaced points in the off landslide area. This resulted in the value of $3.6 \mathrm{~m}$. The tie points were automatically identified in the ortho-images produced during the derivation of the two DEMs, which provide abundant image structures for point identification. This way the problem of tie point identification between two DEMs, which provide no suitable patterns for feature matching, was circumnavigated. Both ortho-images and both the DEMs were resampled to $2.5 \mathrm{~m}$ beforehand which is the resolution of the DEM from the aerial photographs and also approximately of the PRISM ortho-image. Residual distortions of the pre-event DEM in a vertical direction were modeled by a second order polynomial fitted to a regular grid of $20 \times 20$ points representing the elevation differences between the two DEMs. Points falling onto the landslide as well as points with outlying values of elevation difference 
were excluded from the fitting. The higher polynomial order was needed to account for a non-linear distortion of the pre-event DEM probably due to an inaccuracy of the fitted camera model.

\subsection{Vertical Elevation Differences Derived by ICESat}

The study area is crossed by one nominal ground track of ICESat (Ice, Cloud, and land Elevation Satellite) (see Figure 1). The single repeat tracks do not exactly match the nominal nadir track because the ICESat's precision spacecraft pointing control was not used in the mid latitudes (NSIDC 2015). The maximum spread of ground tracks reaches $2.0 \mathrm{~km}$ over the study area. The GLAS instrument (Geoscience Laser Altimeter System) on-board ICESat measured the surface elevation of signal footprints with a diameter of $70 \mathrm{~m}$ along the nadir tracks each $172 \mathrm{~m}$. The data were acquired every 3-6 months during 18 one-month campaigns between 2002 and 2009. The elevation is derived from the two way travel time of the emitted laser pulse and from the position of the satellite. Data records containing the elevation are provided by NSIDC (National Snow and Ice Data Center). We used the ICESat product L2 Global Land Surface Altimetry Data denoted as GLA14, release 34 [38]. This satellite mission was primarily dedicated to monitoring atmospheric aerosol and ice sheets with monotonous terrain and low inclination. We followed an approach that has been successfully used for mountain glaciers with a similar size and topography to large landslides [39-41].

To derive the elevation changes over the landslide body we calculated differences of the ICESat elevation measurements with respect to the pre-event SRTM DEM for each ICESat point. The elevation corresponding to the ICESat measurements was obtained using bi-linear interpolation of elevations of the four neighboring cells in the SRTM DEM. To account for the effect of clouds we discarded all points with the elevation difference $>200 \mathrm{~m}$. Furthermore, we selected points acquired after the initial sliding event given by several authors as being on 13 September 2005 over the study area. This resulted in 40 point measurements distributed mainly over the accumulation area of the landslide. For a reliable estimation of the elevation differences the two datasets were accurately co-registered following [42]. The horizontal shift of the SRTM DEM with respect to the ICESat dataset was estimated as being 30 meters with an azimuth of 31 degrees. This shift was removed by an adjustment of the reference coordinated from the SRTM DEM dataset. As the ICESat elevation is referred to the TOPEX/Poseidon Ellipsoid we subtracted the geoid height provided in the ICESat data records and applied a conversion to the WGS84 ellipsoid following [43] to obtain an elevation coherent with the elevation contained in the SRTM DEM dataset. The error ranges were estimated following [44]. The resulting elevation differences on the ICESat points were compared to the results of the DEM differencing. To assess the uncertainty of the vertical offsets the differences between ICESat measurements and the SRTM were averaged for the same ICESat track over a distance of $70 \mathrm{~km}$ stretching over both plains and slopes including 4600 points. This resulted in a mean difference of $-1.8 \mathrm{~m}$ and standard deviation of 11.6. A threshold of the elevation difference of $100 \mathrm{~m}$ was applied beforehand to sort out ICESat measurements affected by clouds and atmospheric noise [41].

\subsection{Mapping of Surface Features from the Time Series of Optical Satellite Data}

Surface features and patterns identified on remote sensing images of landslides can reveal information on their origin and controlling mechanisms [7,45]. A time series of VHR images was used to analyze the evolution of the slope failure (Table 1). These features are commonly mapped using aerial or drone photographs [45-47], however, the large scale of the Debre Sina landslide allowed us to use also satellite images (Figure 4). We assembled a time series of VHR scene subsets for the landslide and surroundings from the archive of DigitalGlobe ${ }^{\mathrm{TM}}$ and from the European Space Agency (the entire scene from Kompsat-2). The images document slope deformations in the period from 2005 to 2014. Only the WorldView-2 image from 2014 was partially cloud-covered (11\%). Apart from the WorldView-1 image, which has only a panchromatic band, all of the images are composed of a panchromatic band, three visible bands, and one near infrared band. 
The first image was acquired only three months after the presumed initial slope failure that occurred in September 2005 [22]. The images were delivered in a pre-processed form, which means that standard radiometric and geometric corrections have already been applied. The images were ortho-rectified in Leica Photogrammetry Suite (LPS) applying the Ratio Polynomial Coefficients approach using a set of 6 GCPs and 6 check points identified in GoogleEarth in the areas around the body of the landslide. We used a post-event DEM derived from ALOS/PRISM data from 19 November 2008 as the elevation reference. To check the influence of the DEM on the spatial accuracy of the ortho-images, we generated two ortho-images from QuickBird-2 data for 2010 using the post-event PRISM DEM and the global SRTM DEM with grid spacing of one arc second corresponding to 30 meters $[48,49]$. The ortho-images were compared by feature matching in AutoSync, which is included in the Erdas Imagine software package. The influence of the choice of the DEM appears to be low as the RMSE of the identified homologous points was $4.42 \mathrm{~m}$ for the area of the landslide and $2.28 \mathrm{~m}$ for an adjacent area.

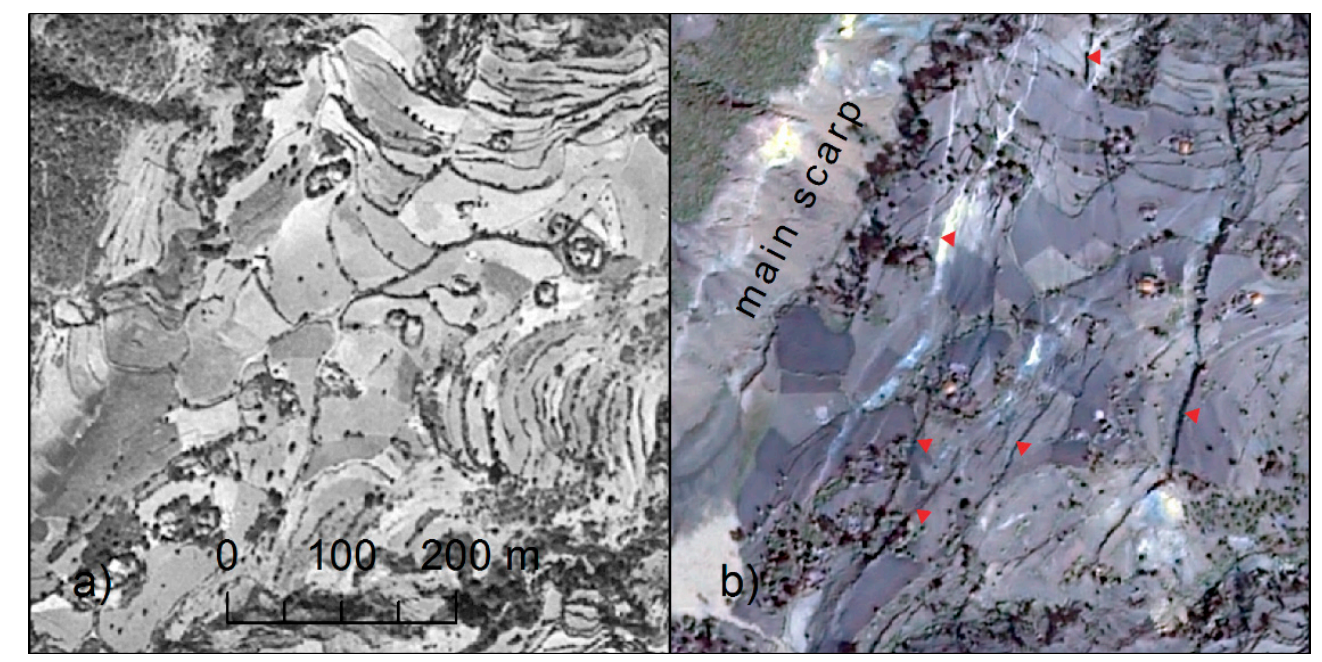

Figure 4. Comparison of ortho-images from aerial photographs taken on 27 November 1986 (a) and from Kompsat-2 taken on 27 January 2008 (b) for an area in the upper part of the landslide (For its position see the Section 4.2). The main scarp, secondary scarps and open cracks are clearly visible. The scarps facing the SE appear as bright lines, whereas the open cracks and scarps facing the E and NE (back-scarps) are dark. The position of the subset is indicated in the Figure 7.

The ortho-image of Ikonos-2 from 2005 is affected with a higher uncertainty in position as there is no DEM available capturing the landslide surface between the two major phases. Since we used the post-event DEM for the orthorectification, the error in position can in theory reach up to $3.1 \mathrm{~m}$ per $10.0 \mathrm{~m}$ meters of elevation difference as the off-nadir angle of the acquisition was $17.5^{\circ}$. Assuming the maximal horizontal difference of $25 \mathrm{~m}$, which is the half of the maximal difference resulting from both the major movement phases, we can estimate the uncertainty of the Ikonos- 2 image from 2005 due to the DEM as $6.0 \mathrm{~m}$.

As we used ground control with unknown accuracy, we could not guarantee a high absolute positional accuracy of the ortho-images. However, our aim was to derive information on the relative movement of the landslide surface with respect to the stable surrounding terrain. This could be achieved by an accurate co-registration of the ortho-images before the application of feature tracking. We applied an automatic tie point identification and co-registration using polynomial adjustment in AutoSync. The Ikonos-2 image from 2005 was used as the master image (Table 1).

To assess the residual error a set of tie points between each image and the Ikonos-2 image from the year 2005 was identified in the off-landslide area. These tie points were selected independently from the previously used ground control points (GCPs). The RMSE of the residuals on the tie points 
was $<2 \mathrm{~m}$ for all of the ortho-images (Table 1). The ortho-image from the aerial photographs that captured the situation before the first movements (described below), and is thus the first image of the time series, was co-registered in the same way. In this case, the RMSE was higher $(6.3 \mathrm{~m})$.

The accurately co-registered ortho-images allowed us to map in detail a number of surface features indicating the mass movement. The main scarp, minor scarps, small water bodies and a large number of cracks were identified and mapped. Contrast manipulation and RGB combinations of the visible and near infrared bands were used to fully exploit the potential of the images. The cracks already identified in a previous image and shifted to a new position were not mapped twice but only in the image of the first occurrence. The mapping was validated during a field trip in March 2015 (Figure 5).
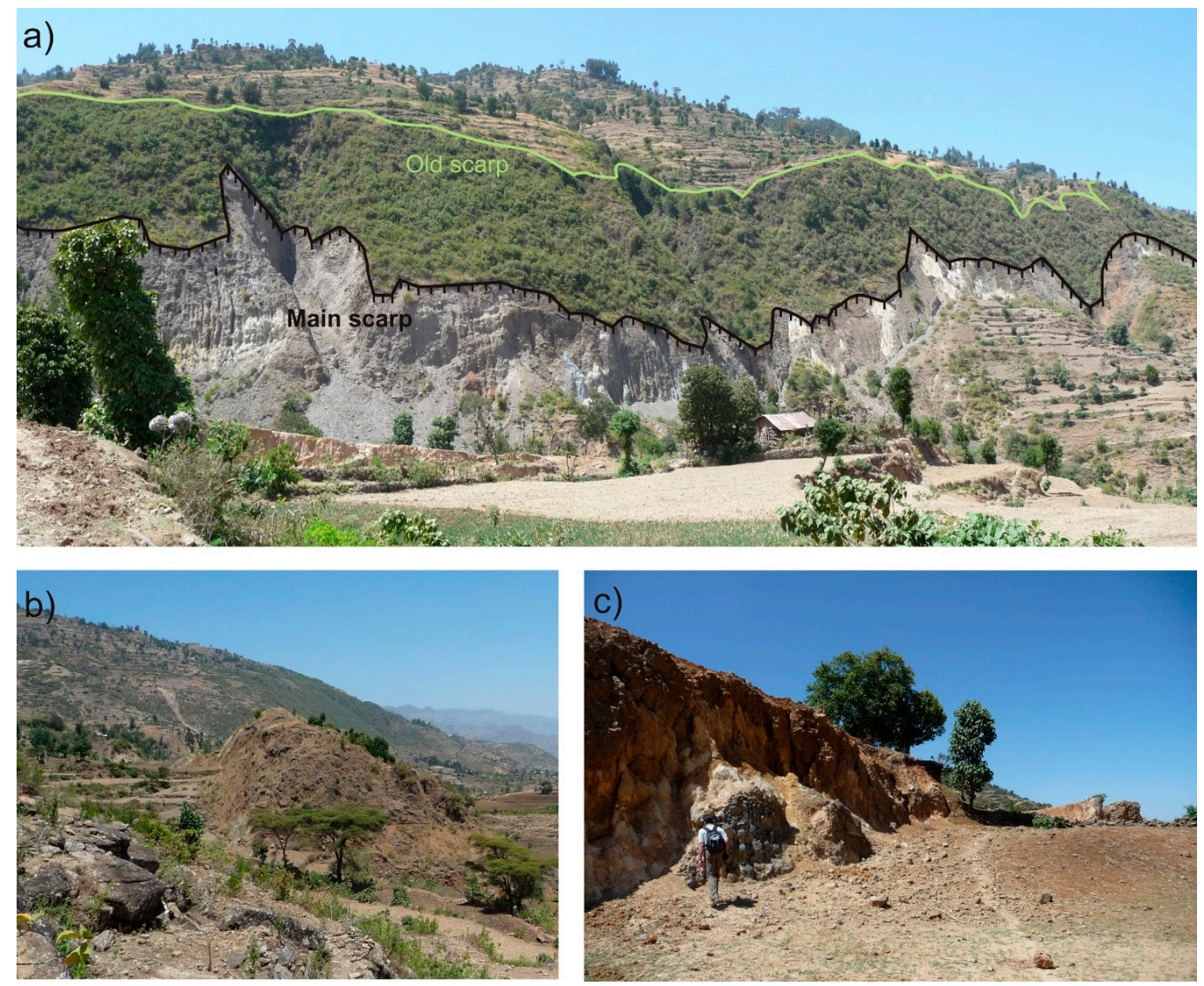

Figure 5. The main scarp of the Debre Sina landslide, which is bordered from above by an old scarp now covered by shrubs (a); A large block of weathered volcanic rock, which was displaced by approximately 90 meters (b); Back-scarps in the main landslide body can reach up to $15 \mathrm{~m}$ in height (c). All photographs were taken by Zuana Vařilová in March 2015.

\subsection{Estimation of Horizontal Displacement by Feature Tracking in Optical Satellite Data}

Following $[7,33,50]$ we applied an automatic approach for the extraction of vectors of horizontal surface movement of a landslide from a time series of remote sensing images. We used feature tracking in a frequency domain implemented in the COSI-Corr tool [5] to automatically extract the magnitude and azimuth of the surface displacements. The images of the time series (Table 1) were down-sampled to $4 \mathrm{~m}$ to minimize the effects of small noisy features and each two consecutive images were matched. Feature matching in frequency domain with initial and final window sizes of 32 and 128 pixels, respectively, was applied in a regular grid with spacing of $128 \mathrm{~m}$. The resulting movement vectors have to be checked for outliers [7]. The vectors of excessive length and direction 
not following the slope inclination were checked against the satellite images and in the event of a discrepancy were manually discarded. The error of displacement magnitudes due to the image co-registration was estimated as the RMS of amplitudes in the off-landslide area, which yields $4.0 \mathrm{~m}$ for 2004 (Kompsat-2 and Ikonos-2) and $8.9 \mathrm{~m}$ for 2005 (aerial photographs and Ikonos-2). The total error of the displacement magnitudes was calculated taking into the account also the error due to the used DEM $(6.0 \mathrm{~m})$, which yielded $10.1 \mathrm{~m}$ and $7.2 \mathrm{~m}$, respectively.

The matching of Ikonos- 2 images from 2005 and 2007 provided poor results. This was due to the difference in phenology and illumination conditions as the 2007 image was acquired in June while most of the other images were taken in winter. The next image of the time series was used instead (Kompsat-2 image from 2008). As a visual check of the shifts between the Ikonos-2 from 2007 and Kompasat-2 images revealed no changes, the resulting vectors represent the movements after the rainy season in 2006. We calculated the gradient of the displacement fields to better understand the kinematics of the landslide. We applied a simple approach based on plane fitting to the values of displacement in a floating window 3 by 3 pixels using the Least Square technique. To account for the noise, the displacement images were median filtered beforehand. The gradient was estimated as the range of the fitted values and converted to $\mathrm{m} / \mathrm{m}$ units.

\subsection{Estimation of Horizontal Displacement by Amplitude Tracking in Microwave Domain}

Two ascending scenes, acquired by ASAR (Advances Synthetic Aperture Radar) instrument on Envisat on 31 July 2004 and 29 October 2005, were obtained from the archive of the ESA. The first represents the situation before the slope failure while the second corresponds to the time period between the initial and the second movement. To account for the inaccuracies in the orbital parameters a co-registration with sub-pixel accuracy was applied to the image pair using cross-correlation function in $32 \times 64$ window. Surface displacements in slant and azimuth directions between the scenes were detected using the amplitude tracking module of the GAMMA software package. SAR amplitude tracking is a suitable method for measuring surface displacement over landslides [51]; however, its results are sensitive to the search window size, which in theory should not be less than the estimated ground displacement [15]. Different window sizes for different SAR sensors were tested and discussed for glacier studies by [15]. In this study, a window size of $32 \times 64$ single-look pixels was used, which corresponds to approximately $640 \mathrm{~m}$ in the ground-range direction and $256 \mathrm{~m}$ in the azimuth direction. Following [51] a high signal to noise ratio (SNR) value of 11 was applied to ensure high coherence. The resulting displacements in range and azimuth directions were projected to the horizontal plane using the local incidence angle and then converted to magnitude using Euclidean geometry. Further, the magnitudes were checked for outliers and manually corrected. The gaps were closed using ordinary kriging [52] interpolation which resulted in a regular grid of displacement values with grid spacing of $120 \mathrm{~m}$. The arrows in the off-landslide area is probably due to the difference of velocities as the size of the processing window is optimized to certain displacement magnitude and can therefore produce noise in the area of no movements [10].

\section{Results}

\subsection{Structural Predispositions for the Mass Movements in the Area}

An expert-based morphostructural analysis of the MER escarpment around Debre Sina using SRTM DEM revealed major morpholineaments striking SSW-NNE (Figure 6). These topographic features most probably represent traces and scarps of tectonic (normal) faults related to the African rift, which also provide evidence of an extensional regime in the area of the landslide. Several minor morpholineaments striking NE-SW, NW-SE, E-W, and N-S are dissected by the major ones and are probably of older age.

Areas affected by slope failures were indicated by large concave scarps, irregular instead of strata-controlled topography, and a convex slope foot, etc., and they were also mapped by the 
morphostructural analysis of the SRTM DEM. The results revealed an extremely large extent of gravitational slope failures in the broader area of the MER escarpment (Figure 6); slope failures covered approximately $126 \mathrm{~km}^{2}$ of study area, which is approximately $12 \%$ of the area shown in the Figure 6. These morphologically significant slope failures are mostly represented by rotational deep-seated rockslides and large earthflows.

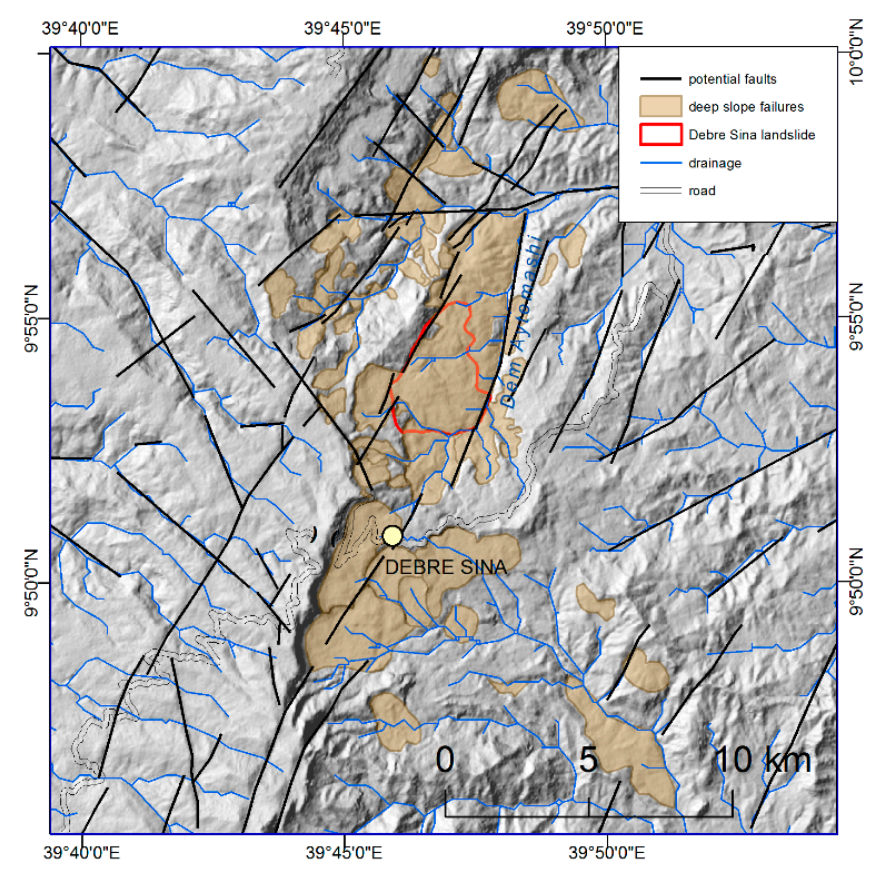

Figure 6. Morphostructural analysis of the SRTM DEM of the surroundings of the Debre Sina landslide revealed a number of areas affected by old deep seated slope failures of the MER escarpment.

\subsection{Surface Morphology and Extent of the Landslide}

A detailed look at the Debre Sina landslide using satellite images (Table 1) revealed a pattern of topographic features on the main body of the slide, as well as the relatively shallower subsequent slope failures (Figure 7). The field survey revealed that the majority of the mapped cracks featured a vertical displacement, i.e., they represent scarps or back-scarps (Figure 5). Most of the scarps and open cracks were found on the first and second images of the time series (Table 1), corresponding to movements after the rainy seasons of 2005 and 2006. Several cracks appeared after the rainy season of 2007. No cracks were found on the later images indicating that no major re-activation has occurred since 2007. The shape of the cracks indicates the rotational character of the movement in the upper part of the affected slope.

According to our observations, especially on zones of high displacement gradients, the extent of the main landslide is approximately $6.5 \mathrm{~km}^{2}$. The lower margin of this zone marks the presumed outcrops of the shear plane of the main landslide. The total area of the Debre Sina landslide, including the relatively shallow subsequent landslides, is $4.7 \mathrm{~km}$ in an N-S direction and $3.5 \mathrm{~km}$ in an E-W direction, which is approximately $8.5 \mathrm{~km}^{2}$. The elevation difference between the crown and the toe is approximately $500 \mathrm{~m}$, taking into the account only the main landslide. The subsequent landslides reached the bottom of the valley, which is $150 \mathrm{~m}$ lower. The maximum estimated thickness of the active main landslide body is approximately 150-200 m according to the interpretation of the topographic profiles, whereas the maximum thickness of the old slope failure is up to $300-400 \mathrm{~m}$ (Figure 8). To estimate the landslide volume we used an empirical formula for rotational landslides by [53]: $V_{L s}=1 / 6 \pi D_{d} \cdot W_{d} \cdot L_{d}$, where $V_{L s}$ is the landslide volume after the movement including 
loosening of the mass, $\mathrm{D}_{\mathrm{d}}$ is the landslide depth, $\mathrm{W}_{\mathrm{d}}$ is the width of the landslide, and $\mathrm{L}_{\mathrm{d}}$ is the length of the landslide. Assuming a thickness of $200 \mathrm{~m}$, the estimated volume of the active main landslide body is approximately $1.7 \mathrm{~km}^{3}$.

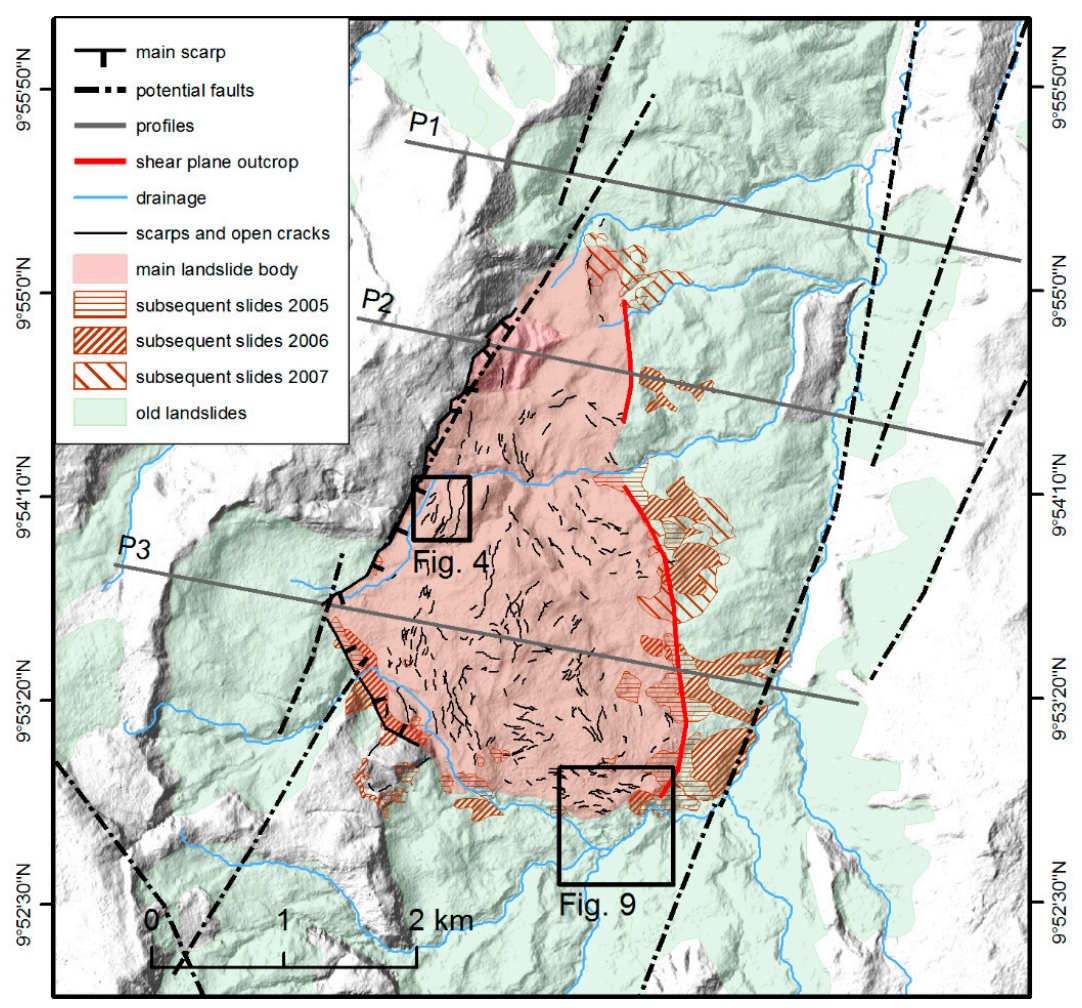

Figure 7. The main scarp coincides with the tectonic lineament. The main landslide body is followed by subsequent relatively shallow landslides below the presumed outcrop of the shear plane.

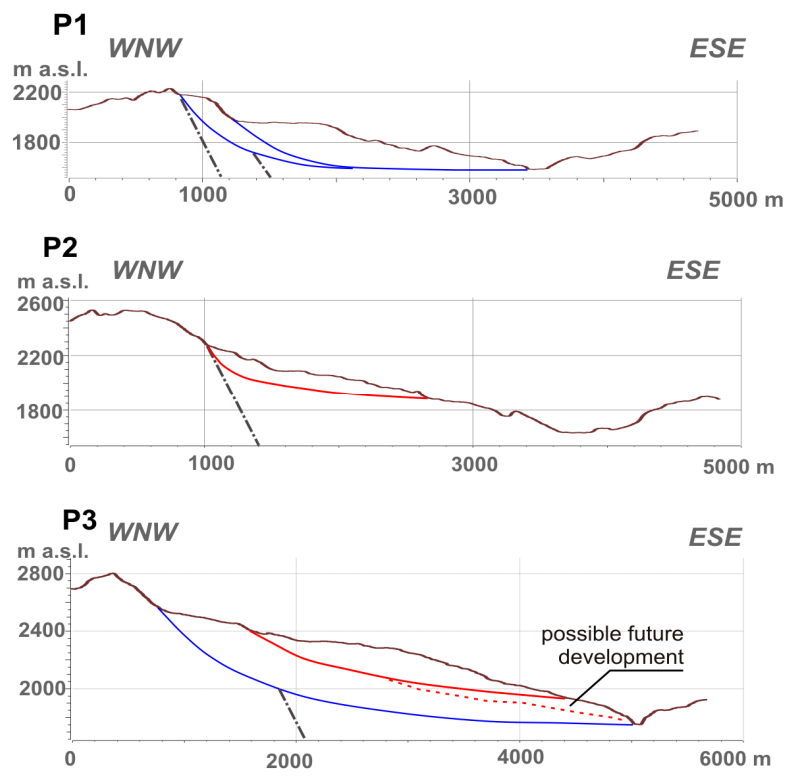

Figure 8. Topographic profiles and interpreted cross-sections of the slope failure under study: the estimated basal shear zones of old slope failures are presented in blue, the active slope failures are in red, and tectonic faults are marked as purple dash-and-dot lines. 
The time series of the satellite images revealed that the southern part of the landslide was more active and the deep-seated mass movements reached the bottom of the valley in the SE. The river was blocked temporarily in 2005 leading to the emergence of a small lake (1.1 ha) and to a diversion of the river course approximately $150 \mathrm{~m}$ to the south (Figure 9).

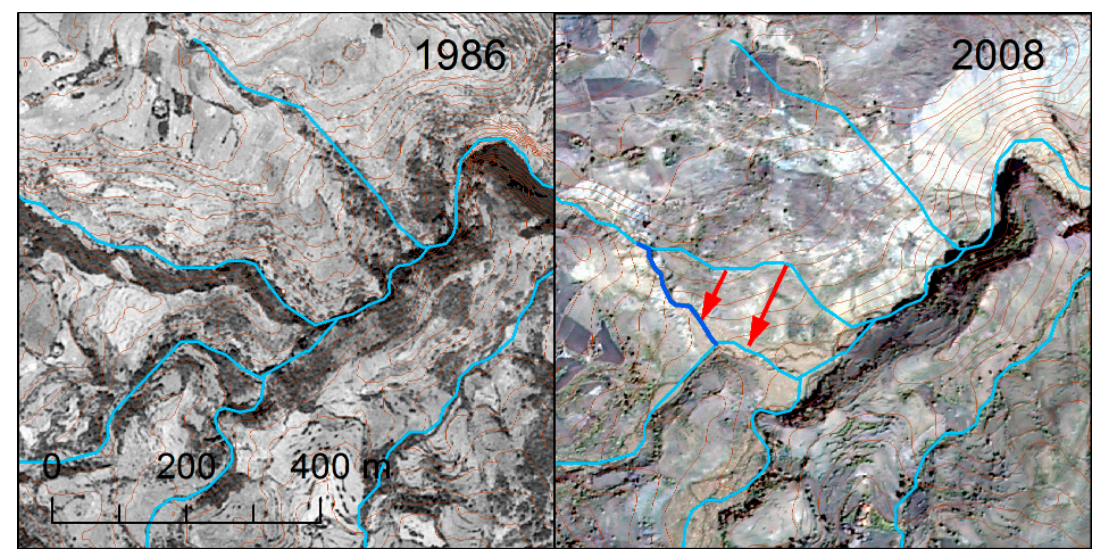

Figure 9. Change of the drainage pattern on the southern margin of the Debre Sina landslide. The position of the subset is indicated in the Figure 7.

\subsection{Horizontal Displacements Revealed by Feature Tracking}

The displacement fields derived from the satellite images clearly document that the main movements occurred in two phases after the rainy seasons of 2005 and 2006 (Figure 10). The amplitude of horizontal movements reached up to $48 \pm 10.1 \mathrm{~m}$ and $114 \pm 7.2 \mathrm{~m}$ in the first and second phase, respectively. It can be seen that the movement vectors are divergent (Figure 10), which means that lateral spreading took place in both phases. Both the displacement fields show that the lower part of the slope between the landslide body and the river remained stable during both of the major movement phases. Furthermore, it can be observed that the displacement magnitude increases towards the lower part of the slope within the main landslide. This indicates surface extension in both the lateral and transversal extension. The displacements also increase in an N-S direction, which could be due to higher infiltration above the southern part of the main landslide indicated by the high values of TWI (Figure 3).

The displacement fields of all of the other subsequent image pairs covering the period 2007-2014 do not show any coherent pattern over the landslide area. Furthermore, the magnitudes of these displacement fields do not exceed the RMS of the displacements in the off-landslide area, which means that they represent noise. This implies that there were no displacements or their magnitude was lower than the level of noise. As no cracks were detected in the VHR images after 2007 and no reactivation was reported by the local inhabitants interviewed by [23], we conclude that the slope stayed stable after 2007.

The displacement field from the amplitude tracking is in good agreement with the feature tracking in the optical domain (Figure 10). Its theoretical accuracy was calculated following [13] as being $0.3 \mathrm{~m}$; however, the real error is much higher as the vectors identified in the off-landslide area result in an RMSE of $6.6 \mathrm{~m}$.

The gradients derived from the displacement field for movements in 2005 and 2006 (Figure 11) provide detailed information on the kinematics of the slope failure. The gradient images feature spatial patterns of belts of high gradient that are bordered by zones of low gradient which correspond to areas of similar movement magnitude. The belts of high gradient partially correspond to the zones of open cracks and secondary scarps. 


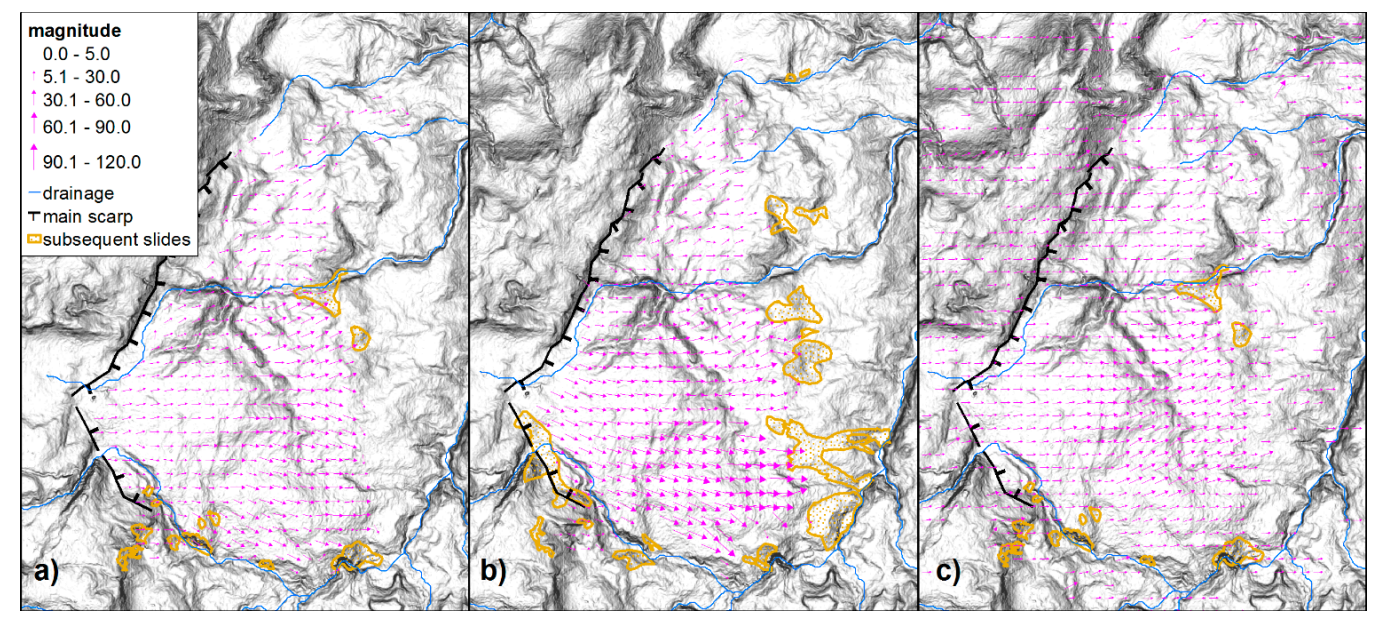

Figure 10. Vectors of horizontal displacements of the two major phases of activity from the feature tracking in the optical domain in 2005 (a) and 2006 (b). Aerial photographs from 1986, Ikonos-2 image from 14 December 2005 and Kompsat-2 image from 27 January 2008 were used for the feature tracking. No vectors could be derived for the relatively shallow subsequent landslides as their surface was disturbed during the sliding. The displacement field from Envisat/ASAR images from 31 July 2004 and 29 October 2005 indicates that the major movements in 2005 took place before the end of October (c). The vectors in the off-landslide area (also above the main scarp) are considered to be noise. The slope inclination map based on the pre-event DEM is shown in the background.

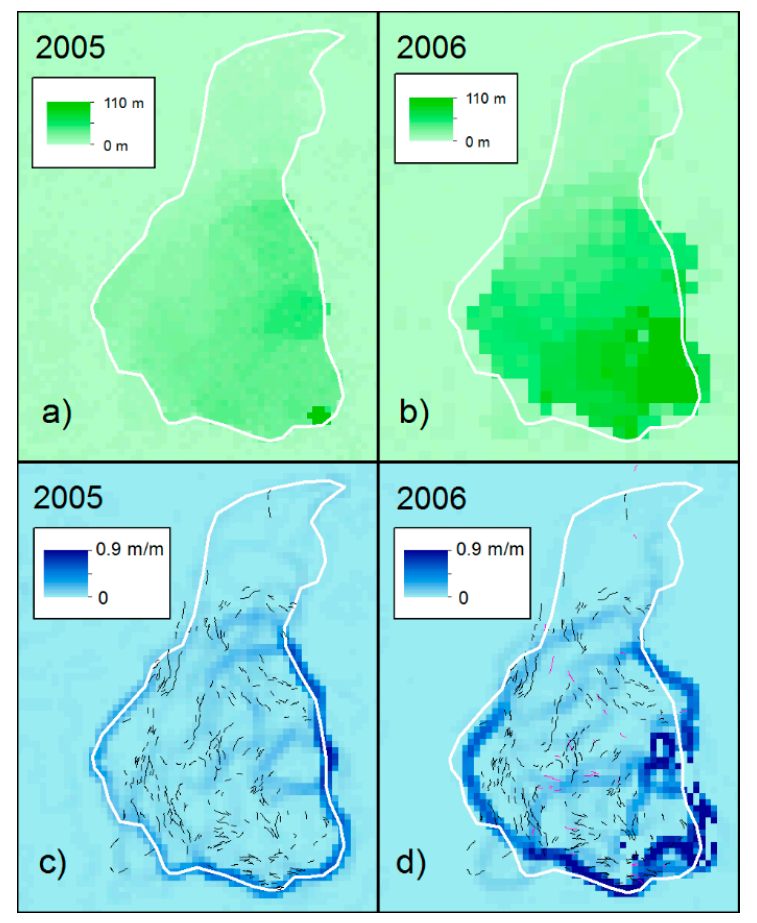

Figure 11. Magnitude of horizontal movements calculated by feature tracking from VHR images for the movement phases in 2005 (a) and 2006 (b). Gradients of displacement for 2005 (c) and for 2006 (d) represent surface deformation patterns. The extent of the main landslide body activated in 2005 is shown as a white outline in all sub-images showing the change in the extent of the landslide area in 2006. Scarps and open cracks longer than 50 meters are shown as black (2005) and magenta (2006) lines. 


\subsection{Vertical Displacements Identified by Differential DEMs}

The map of vertical displacements (Figure 12) shows the total change in vertical direction in the period from 1986 to 2008 and thus comprises both the 2005 and 2006 events. The map shows zones of elevation decrease in the upper part of the main body reaching $-42 \pm 3.6 \mathrm{~m}$ and zones of elevation increase in its lower part showing the displacement of the mass with vertical differences reaching $49 \pm 3.6 \mathrm{~m}$ (Figure 12). This pattern corresponding to depletion and accumulation distinguishes the deep seated movement of the main body from the subsequent shallower landslides. Furthermore, detailed information such as the thickness of sediment filling of the valleys by mobilized unconsolidated material can be retrieved from the difference image. The depth of the filling along the southern margin of the main landslide reaches around $47 \pm 3.6 \mathrm{~m}$. Another pattern clearly visible in Figure 12 is an interleaving of zones of positive and negative elevation differences in the middle part of the main landslide. These zones correspond to a replacement of surface undulations already present in the pre-event DEM, leaving areas of negative elevation differences in their original position and creating areas of positive differences in the new position. One of these ridges oriented in a NW-SE direction is formed by deeply weathered volcanic rock surrounded by unconsolidated colluvial material (Figure 5b). The DEM difference also captured a large rock fall that transformed the main scarp in the SW part of the landslide (Figure 2a).

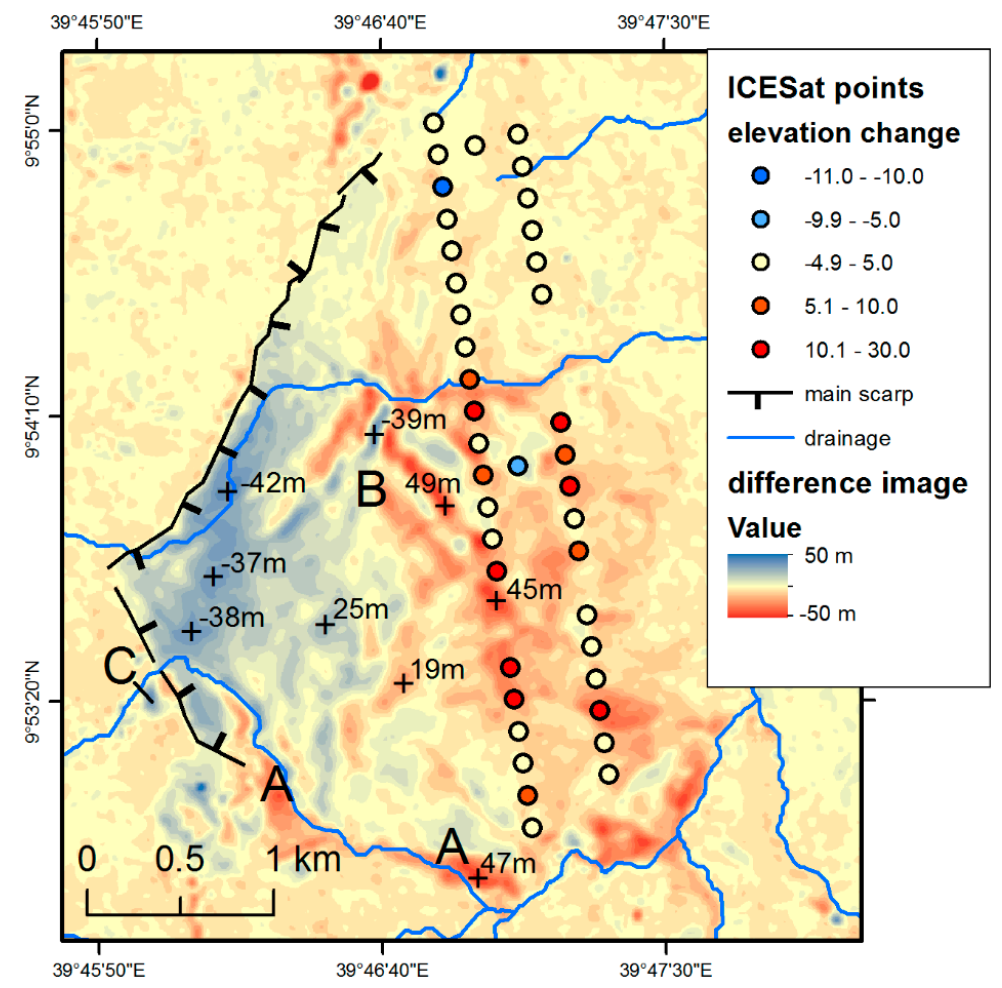

Figure 12. Elevation changes calculated from the pre-and post-event DEMs. The filling of valleys by mobilized sediment can be clearly seen (A). The stripes of negative values followed by stripes of positive values in the central part of the landslide are due to a shift of terrain ridges. Negative and positive areas mark their original and new positions, respectively (B). A large rock fall beyond the main scarp is marked by $(\mathbf{C})$. The point rows across the accumulation area represent elevation changes derived as a difference between the ICESat measurements and the pre-event DEM. The points follow three satellite ground tracks from 17 June 2006, 2 April 2009 and 8 December 2008 (from W to E).

Three usable ICESat ground tracks that cross the accumulation part of the main landslide body (Figure 12) contain 39 point measurements yielding elevation differences ranging from $-11.0 \mathrm{~m}$ to $24.6 \mathrm{~m}$. One track was acquired between the two major phases of the movement (17 June 2006) while 
the two remaining tracks were acquired after the second phase. Over land, single elevation differences can be affected by inaccuracies due to various influences including local surface slope, roughness and errors in fitting the return waveform [54]. However, the elevation changes extracted by the two different methods feature a high correlation $(r=0.92)$. Only the points of the two tracks acquired after the second movement phase (19 points) were used for the correlation. To our knowledge this is the first time that a combination of ICESat data and DEM was used to measure vertical elevation changes of a landslide surface.

\section{Discussion}

\subsection{Character of the Movement}

The displacement fields revealed an extension in a longitudinal direction and lateral spread. The lateral spread is further confirmed by the existence of scarps and open cracks in a longitudinal direction (Figure 7). In addition, a higher movement magnitude in the southern part of the main landslide can be seen in both the displacement fields (Figure 10). This irregularity may be due to higher infiltration above this part, as indicated by the TWI (Figure 3).

The 3D reconstruction based on the aerial imagery resulted in detailed DEM but the lower geometrical quality affected the accuracy of feature tracking. Nevertheless, the accuracy was sufficient to map the movements as its amplitude reached values one order of magnitude higher than the error. The huge elevation differences detected by DEM differentiating were a good indication of the depth of the slope failure. The differential DEM allowed us to delineate the main deep-seated landslide body from the subsequent shallower landslides. We could also identify the largely unaffected lower part of the slope. It is remarkable that large areas (Figure 7) of the main landslide body feature little change to the original surface despite significant horizontal movements.

\subsection{Evolution of the Slope Failure}

The analysis of the VHR images of the Debre Sina slope failure showed that there were large movements before 14 December 2005 and between 14 December 2005 and 5 June 2007. The displacement field from Envisat/ASAR shows that the first phase took place after 31 July 2004 and before 29 October 2005. Based purely on the VHR image analysis, we could not decide whether a continuous or abrupt movement took place. However, taking into account that the main triggering factor of landslides on the rift margin is rainfall $[19,21,55]$ we can suppose that the main movement of the Debre Sina landslide occurred in two phases after the rainy periods of 2005 and 2006. This agrees with the findings of [24] who carried out interviews with local inhabitants. We could also see that the extent of the main landslide was almost identical in both phases. In addition, we could measure the amplitude of the horizontal movements, which revealed that the second phase had higher amplitude than the first one. Furthermore, we could assess the position of the outcrop of the shear plane. The shear plane outcrop was presumed to be much deeper by $[23,26]$ but the feature tracking and the DEM differencing clearly showed that the lower part of the slope was only partially affected by relatively shallow movements. These subsequent landslides were caused by a collapse of pushed out material along the shear plane of the main body. It can be expected that the landslide will prograde in this area and it will eventually reach the river [55].

Large shallow landslides were still occurring on the slope below the shear plane outcrop in 2007. The present processes mainly affect the disturbed surfaces of the shallow landslides and they have a prevalently water erosion character. Some of these disturbed areas are also the subject of small scale remediation measures by local farmers such as terracing on the denudated surface of shallow landslides. 


\subsection{Predisposition and Triggering}

Regarding the predisposition of the Debre Sina landslide, the active tectonics, seismic activity and thick sediment mantle on the long slopes of the MER clearly provide favorable conditions for the occurrence of large mass movements. The morphostructural analysis of the wider surroundings identified a number of old landslides in similar settings to the Debre Sina landslide (Figure 6) and clearly showed the tectonic predisposition of the landslides which agrees with the findings of [22]. The occurrence of the Debre Sina landslide has a very close resemblance to the rejuvenation of part of a boundary fault system in the Tarmaber area (Ankober border fault) $[23,56]$. Although it may be difficult to distinguish the origin of many of the terrain forms in a tectonically highly active area [57] the fault that is followed by the main scarp could be clearly identified in both pre- and post-event DEMs. The convex form of the landslide body, which is evident in both the pre- and post-event DEMs (Figure 3), indicates that the studied slope failure is probably a re-activation of an old large landslide. This finding is further supported by the existence of a steep slope covered with vegetation above the main scarp that has almost the same inclination and forms a continuous stripe above the present scarp (Figure 5a).

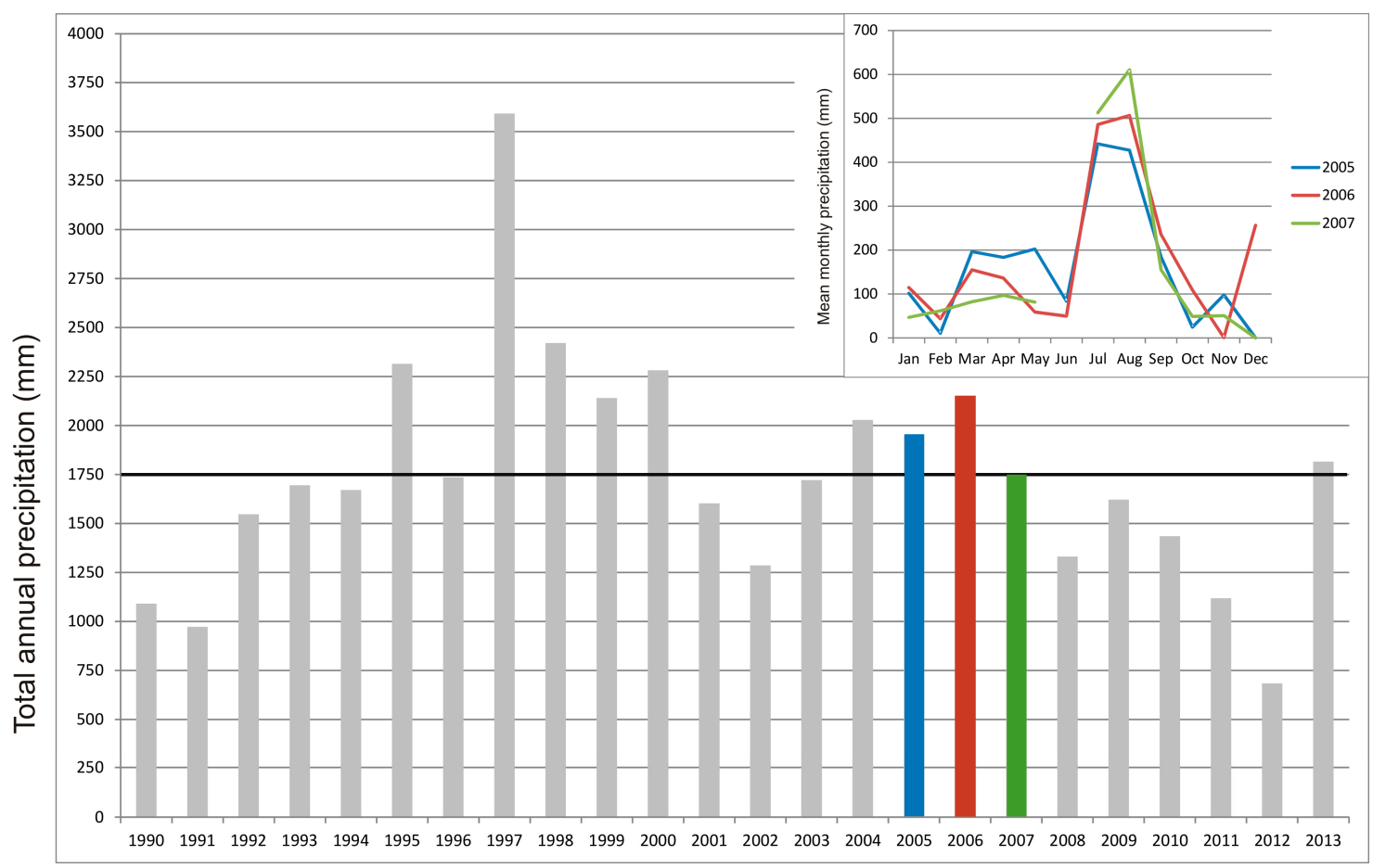

Figure 13. More than 20 years (1990 to 2013) of rainfall records from the Debre Sina station operated by the National Meteorology Agency of Ethiopia. The mean annual precipitation for the whole period marked by a horizontal black line is $1750 \mathrm{~mm}$. The inlet graph of mean monthly precipitation in 2005, 2006 and 2007 shows periods of intensive rainfall in July and August.

A triggering of the Debre Sina landslide by an earthquake was suggested by several authors. A series of 162 earthquakes with magnitude $>4$ connected to volcanic exposures in the Affar region in the period between 20 September and 4 October 2005 [58,59] and was identified as a trigger of the 2005 movement by [22]. However, the main movement in 2005 occurred sooner on 13 and 14 September $[22,24,26]$ Furthermore, we were unable to find any seismic record corresponding to the largest 2006 event that also occurred in September [20]. Taking into account the huge volume, we presume that the main triggering factor is precipitation cumulated over a period of several months. However, the initiation of the movement can be due to a ground tremor. A single precipitation event listed in [22] as the daily maximum rainfall is unlikely to trigger a slope failure of such a large 
extent. The precipitation records taken directly in Debre Sina show that the years 2005 and 2006 were above average but not extreme (Figure 13). We suggest that the sliding events were driven by a combination of geologic and tectonic predispositions together with external factors such as long-term water saturation and/or seismic events.

\section{Conclusions}

This study demonstrated the high potential of remote sensing techniques for the investigation of a large landslide with difficult accessibility. Using a number of approaches, some of them rarely used for landslides, we were able to carry out a new and detailed interpretation of the Debre Sina landslide. A combination of these techniques with the support of a limited field survey provided us with information about the landslide concerning its extent, kinematics, zonation and evolution over time.

The displacement fields derived by feature tracking in an optical domain provided us with quantitative information related to the particular phases of the slope failure development. Furthermore, we could distinguish the main landslide body from the subsequent shallower slides and identify the stable lower part of the slope affected only by the shallower movements. The amplitude tracking using archive Envisat data provided a lower resolution than the optical VHR images and appeared to be sensitive to processing parameters; nevertheless, its results allowed us to narrow the time window of the first landslide phase. In addition, it provided an independent validation of the results from the optical domain.

The DEMs derived by different techniques from historical aerial photographs and from modern stereo acquisitions appeared to show high potential for the general analysis of the extent and type of movements as well as for detailed feature identification. The derivatives of the detailed pre-event DEM such as TWI or slope inclination appeared to be useful tools for understanding the fine morphology and processes leading to the development of the slope failure. Our only high resolution pre-event dataset relies on an old aerial image from the EMA. This highlights the importance of national archives of aerial photographs reaching far before the era of VHR satellites. The good management of such archives ensuring easy accessibility and digitalization of analogous media is inevitable for the evaluation of this precious data source.

The analysis of ICESat measurements over the accumulation part of the main landslide body matches the results of the DEM differencing. Furthermore, it provides an independent validation. To our knowledge, this was the first time that a landslide accumulation was measured by a satellite laser altimeter. This indicates the potential of future satellite altimetry missions for the measurement of slope deformations.

Detailed terrain information representing the juxtaposition of the DEMs with the VHR images allowed us to identify a number of detailed features such as the appearance of temporary water bodies or changes of the river course and the type of the subsequent landslides. The occurrence and in particular the dimensions of the Debre Sina landslide confirm the high susceptibility of volcanic terrains to large gravitational mass movements in accordance with other published studies worldwide.

Acknowledgments: This study was carried out in the framework of the German Science Foundation (DFG) project "Integrated assessment of geomorphological process dynamics on different spatio-temporal scales in the Ethiopian Highlands using remote sensing and advanced modelling approaches" (HO1840/11-1) and the Czech Science Foundation (GAČR) project "Mass wasting and erosion as an indicator of morphotectonic activity in the Ethiopian Highlands based on remote sensing approaches" (P209/12/J068). The ALOS/PRISM data were provided by the ESA in the framework of the project ID13160. The aerial photographs were provided by the Ethiopian Mapping Agency. We would like to thank the Gesellschaft für Erd- und Völkerkunde, Stuttgart, Germany for supporting the field campaign in 2015. Last but not least, we would like to thank Jiří Šíma from AQUATEST a.s., Prague, Czech Republic and Leta Alemayehu from the Geological Survey of Ethiopia for providing valuable information and useful advice. 
Author Contributions: Jan Kropáček carried out the remote sensing data analyses and wrote a substantial part of the manuscript. Zuzana Vařilová took care of the literature, evaluated the field investigations and took part in the writing of the text. Ivo Baron performed the morphostructural analysis and contributed to the text. Atanu Battacharya carried out the amplitude tracking. Joachim Eberle contributed by performing the field data interpretation. Volker Hochschild managed the project activities and reviewed the text.

Conflicts of Interest: The authors declare no conflict of interest.

\section{References}

1. Kääb, A. Photogrammetry for early recognition of high mountain hazards: New techniques and applications. Phys. Chem. Earth Part B: Hydrol. Ocean. Atmos. 2000, 25, 765-770. [CrossRef]

2. Kääb, A. Monitoring high-mountain terrain deformation from repeated air- and spaceborne optical data: Examples using digital aerial imagery and ASTER data. ISPRS J. Photogramm. Remote Sens. 2002, 57, 39-52. [CrossRef]

3. Delacourt, C.; Raucoules, D.; Le Mouélic, S.; Carnec, C.; Feurer, D.; Allemand, P.; Cruchet, M. Observation of a large landslide on La Reunion Island using differential SAR interferometry (JERS and Radarsat) and correlation of optical (Spot5 and Aerial) images. Sensors 2009, 9, 616-630. [CrossRef] [PubMed]

4. Kääb, A.; Vollmer, M. Surface Geometry, Thickness changes and flow fields on creeping mountain permafrost: Automatic extraction by digital image analysis. Permafr. Periglac. Process. 2000, 11, 315-326. [CrossRef]

5. Leprince, S.; Barbot, S.; Ayoub, F.; Avouac, J.-P. Automatic and precise orthorectification, coregistration, and subpixel correlation of satellite images, application to ground deformation measurements. IEEE Trans. Geosci. Remote Sens. 2007, 45, 1529-1558. [CrossRef]

6. Scherler, D.; Leprince, S.; Strecker, M.R. Glacier-surface velocities in alpine terrain from optical satellite imagery-Accuracy improvement and quality assessment. Remote Sens. Environ. 2008, 112, 3806-3819. [CrossRef]

7. Stumpf, A.; Malet, J.P.; Allemand, P.; Ulrich, P. Surface reconstruction and landslide displacement measurements with Pléiades satellite images. ISPRS J. Photogramm. Remote Sens. 2014, 95, 1-12. [CrossRef]

8. Lacroix, P.; Berthier, E.; Maquerhua, E.T. Earthquake-driven acceleration of slow-moving landslides in the Colca valley, Peru, detected from Pléiades images. Remote Sens. Environ. 2015, 165, 148-158. [CrossRef]

9. Fruneau, B.; Achache, J.; Delacourt, C. Observation and modelling of the Saint-Etienne-de-Tinee landslide using SAR interferometry. Tectonophysics 1996, 265, 181-190. [CrossRef]

10. Rott, H.; Scheuchl, B.; Siegel, A.; Grasemann, B. Monitoring very slow slope motion by means of SAR interferometry: A case study from a mass waste above a reservoir in the Ötztal Alps, Austria. Geophys. Res. Lett. 1999, 26, 1629-1632. [CrossRef]

11. Strozzi, T.; Farina, P.; Corsini, A.; Ambrosi, C.; Thüring, M.; Zilger, J.; Wiesmann, A.; Wegmüller, U.; Werner, C. Survey and monitoring of landslide displacements by means of L-band satellite SAR interferometry. Landslides 2005, 2, 193-201. [CrossRef]

12. Delacourt, C.; Allemand, P.; Berthier, E.; Raucoules, D.; Casson, B.; Grandjean, P.; Pambrun, C.; Varel, E. Remote-sensing techniques for analysing landslide kinematics: A review. Bull. Soc. Geol. France 2007, 178, 89-100. [CrossRef]

13. Strozzi, T.; Luckman, A.; Murray, T.; Wegmüller, U.; Werner, C.L. Glacier motion estimation using SAR offset-tracking procedures. IEEE Trans. Geosci. Remote Sens. 2002, 40, 2384-2391. [CrossRef]

14. Pritchard, H.; Murray, T.; Luckman, A.; Strozzi, T.; Barr, S. Glacier surge dynamics of Sortebræ, east Greenland, from synthetic aperture radar feature tracking. J. Geophys. Res.: Earth Surf. 2005, 110, 1-13. [CrossRef]

15. Jiang, Z.-L.; Liu, S.-Y.; Peters, J.; Lin, J.; Long, S.-C.; Han, Y.-S.; Wang, X. Analyzing Yengisogat Glacier surface velocities with ALOS PALSAR data feature tracking, Karakoram, China. Environ. Earth Sci. 2012, 67, 1033-1043. [CrossRef]

16. Weber, D.; Herrmann, A. Contribution of digital photogrammetry in spatio-temporal knowledge of unstable slopes: the example of the Super-Saute landslide (Alpes-de-Haute-Provence, France). Bull. Soc. Geol. France 2000, 171, 637-648. [CrossRef] 
17. Walstra, J.; Chandler, J.H.; Dixon, N.; Dijkstra, T.A. In time for change-quantifying landslide evolution using historical aerial photographs and modern photogrammetric methods. In Proceedings of the 20th ISPRS, Istanbul, Turkey, 12-23 July 2004; pp. 475-480.

18. Tsutsui, K.; Rokugawa, S.; Nakagawa, H.; Miyazaki, S.; Chin-Tung, C.; Shiraishi, T.; Shiun-Der, Y. Detection and volume estimation of large-scale landslides based on elevation-change analysis using DEMs extracted from high-resolution satellite stereo imagery. IEEE Trans. Geosci. Remote Sens. 2007, 45, 1681-1696. [CrossRef]

19. Abebe, B.; Dramis, F.; Fubelli, G.; Umer, M.; Asrat, A. Landslides in the Ethiopian highlands and the Rift margins. J. Afr. Earth Sci. 2010, 56, 131-138. [CrossRef]

20. Woldearegay, K. Review of the occurrences and influencing factors of landslides in the highlands of Ethiopia: With implications for infrastructural development. Momona Ethiop. J. Sci. 2013, 5, 3-31.

21. Ayalew, L. The effect of seasonal rainfall on landslides in the highlands of Ethiopia. Bull. Eng. Geol. Environ. 1999, 58, 9-19. [CrossRef]

22. Abay, A.; Barbieri, G. Landslide Susceptibility and Causative Factors Evaluation of the Landslide Area of Debresina, in the Southwestern Afar Escarpment, Ethiopia. J. Earth Sci. Eng. 2012, 2, 133-144.

23. Alemayehu, L.; Gerra, S.; Zvelebil, J.; Šíma, J. Landslide Investigations in Tarmaber, Debre Sina, North Shewa Zone; Amhara Regional State; AQUATEST a.s.: Prague, Czech Republic, 2012.

24. Woldearegay, K. Characteristics of a large-scale landslide triggered by heavy rainfall in Tarmaber area, central highlands of Ethiopia. Geophys. Res. Abstr. 2008, 10. EGU2008-A-04506-EGU02008.

25. Schneider, J.; Woldearegay, K.; Atsbah, G. Reactivated large-scale landslides in Tarmaber district, central Ethiopian Highlands at the western rim of afar triangle. In Proceedings of the International Geological Congress, Oslo, Sweeden, 6-14 August 2008.

26. Hagos, A.A. Remote sensing and GIS-based mapping on landslide phenomena and landslide susceptibility evaluation of Debresina Area (Ethiopia) and Rio San Girolamo basin (Sardinia). Ph.D. Thesis, Universita degli Studi di Cagliari, Cagliari, Italy, 2012.

27. Kebede, F.; Kulhánek, O. Recent seismicity of the East African Rift system and its implications. Phys. Earth Planet. Inter. 1991, 68, 259-273. [CrossRef]

28. Keir, D.; Ebinger, C.J.; Stuart, G.W.; Daly, E.; Ayele, A. Strain accommodation by magmatism and faulting as rifting proceeds to breakup: Seismicity of the northern Ethiopian rift. J. Geophys. Res.: Solid Earth 2006, 111. [CrossRef]

29. Midzi, V.; Hlatywayo, D.J.; Chapola, L.S.; Kebede, F.; Atakan, K.; Lombe, D.K.; Turyomurugyendo, G.; Tugume, F.A. Seismic hazard assessment in Eastern and Southern Africa. Ann. Geophys. 1999, 42.

30. USGS. Earthquake Hazards Program. Available online: http:/ / earthquake.usgs.gov/earthquakes/search/ (accessed on 2 September 2015).

31. Gouin, P. Earthquake History of Ethiopia and the Horn of Africa; International Development Research Centre: Ottawa, ON, Canada, 1979.

32. Westoby, M.J.; Brasington, J.; Glasser, N.F.; Hambrey, M.J.; Reynolds, J.M. Structure-from-Motion photogrammetry: A low-cost, effective tool for geoscience applications. Geomorphology 2012, 179, 300-314. [CrossRef]

33. Lucieer, A.; de Jong, S.M.; Turner, D. Mapping landslide displacements using Structure from Motion (SfM) and image correlation of multi-temporal UAV photography. Prog. Phys. Geogr. 2013, 38, 97-116. [CrossRef]

34. Beven, K.J.; Kirkby, M.J.; Seibert, J. A physically based, variable contributing area model of basin hydrology. Hydrol. Sci. Bull. 1979, 24, 43-69. [CrossRef]

35. Conoscenti, C.; Maggio, C.D.; Rotigliano, E. GIS Analysis to assess landslide susceptibility in a fluvial basin of NW Sicily (Italy). Geomorphology 2008, 94, 325-339. [CrossRef]

36. Yilmaz, I. Landslide susceptibility mapping using frequency ratio, logistic regression, artificial neural networks and their comparison: A case study from Kat landslides (Tokat-Turkey). Comput. Geosci. 2009, 35, 1125-1138. [CrossRef]

37. Takaku, J.; Futamura, N.; Iijima, T.; Tadono, T.; Shimada, M. High resolution DSM generation from ALOS PRISM-Perform-ance Analysis. In Proceedings of the IEEE IGARSS, Barcelona, Spain, 23-27 July 2007.

38. Zwally, H.J.; Schutz, R.; Bentley, C.; Bufton, J.; Herring, T.; Minster, J.; Spinhirne, J.; Thomas, R. GLAS/ICESat L2 Global Land Surface Altimetry Data, Version 33, National Snow and Ice Data Center, Boulder, CO, USA, 2003. 
39. Kääb, A.; Berthier, E.; Nuth, C.; Gardelle, J.; Arnaud, Y. Contrasting patterns of early twenty-first-century glacier mass change in the Himalayas. Nature 2012, 488, 495-498. [CrossRef] [PubMed]

40. Neckel, N.; Kropáček, J.; Bolch, T.; Hochschild, V. Glacier mass changes on the Tibetan Plateau 2003-2009 derived from ICESat laser altimetry measurements. Environ. Res. Lett. 2014, 9, 014009. [CrossRef]

41. Kropáček, J.; Neckel, N.; Bauder, A. Estimation of mass balance of the Aletsch Glacier, Swiss Alps, from ICESat laser altimetry data. Remote Sens. 2014, 6, 5614-5632. [CrossRef]

42. Nuth, C.; Kääb, A. Co-registration and bias corrections of satellite elevation data sets for quantifying glacier thickness change. Cryosphere 2011, 5, 271-290. [CrossRef]

43. Bhang, K.J.; Schwartz, F.W.; Braun, A. Verification of the vertical error in C-band SRTM DEM using ICESat and Landsat-7, Otter Tail County, MN. IEEE Trans. Geosci. Remote Sens. 2007, 45, 36-44. [CrossRef]

44. Koblet, T.; Gärtner-Roer, I.; Zemp, M.; Jansson, P.; Thee, P.; Haeberli, W.; Holmlund, P. Reanalysis of multi-temporal aerial images of Storglaciären, Sweden (1959-99)—Part 1: Determination of length, area, and volume changes. The Cryosphere 2010, 4, 333-343. [CrossRef]

45. Parise, M. Observation of surface features on an active landslide, and implications for understanding its history of movement. Nat. Hazards Earth Syst. Sci. 2003, 3, 569-580. [CrossRef]

46. Niethammer, U.; James, M.R.; Rothmund, S.; Travelletti, J.; Joswig, M. UAV-based remote sensing of the Super-Sauze landslide: Evaluation and results. Eng. Geol. 2012, 128, 2-11. [CrossRef]

47. Stumpf, A.; Malet, J.-P.; Kerle, N.; Niethammer, U.; Rothmund, S. Image-based mapping of surface fissures for the investigation of landslide dynamics. Geomorphology 2013, 186, 12-27. [CrossRef]

48. Farr, T.G.; Kobrick, M. Shuttle radar topography mission produces a wealth of data. Eos Trans. AGU 2000, 81, 583-583. [CrossRef]

49. Rabus, B.; Eineder, M.; Roth, A.; Bamler, R. The shuttle radar topography mission-A new class of digital elevation models acquired by spaceborne radar. ISPRS J. Photogramm. Remote Sens. 2003, 57, 241-262. [CrossRef]

50. Booth, A.M.; Lamb, M.P.; Avouac, J.-P.; Delacourt, C. Landslide velocity, thickness, and rheology from remote sensing: La Clapière landslide, France. Geophys. Res. Lett. 2013, 40, 4299-4304. [CrossRef]

51. Raucoules, D.; de Michele, M.; Malet, J.P.; Ulrich, P. Time-variable 3D ground displacements from high-resolution synthetic aperture radar (SAR). Application to La Valette landslide (South French Alps). Remote Sens. Environ. 2013, 139, 198-204. [CrossRef]

52. Krige, D.G. A statistical approach to some basic mine valuation problems on the Witwatersrand. J. Chem., Metall. Min. Soc. South Afr. 1951, 52, 119-139.

53. Turner, A.K.; Schuster, L.R. Landslides: Investigation and Mitigation; Transportation Research Board: Washington, WA, USA, 1996.

54. Hilbert, C.; Schmullius, C. Influence of surface topography on ICESat/GLAS forest height estimation and waveform shape. Remote Sens. 2012, 4, 2210-2235. [CrossRef]

55. Záruba, Q.; Mencl, V. Landslides and Their Control; Elsevier: New York, NY, USA, 1972.

56. Wolfenden, E.; Ebinger, C.; Yirgu, G.; Deino, A.; Ayalew, D. Evolution of the northern Main Ethiopian rift: Birth of a triple junction. Earth Planet. Sci. Lett. 2004, 224, 213-228. [CrossRef]

57. Baroň, I.; Kernstocková, M.; Faridi, M.; Bubík, M.; Milovský, R.; Melichar, R.; Sabouri, J.; Babůrek, J. Paleostress analysis of a gigantic gravitational mass movement in active tectonic setting: The Qoshadagh slope failure, Ahar, NW Iran. Tectonophysics 2013, 605, 70-87. [CrossRef]

58. Wright, T.; Ebinger, C.; Biggs, T.; Ayele, A.; Yirgu, G.; Keir, D.; Stork, A. Magma maintained rift segmentation at continental rupture in the 2005 Afar diking episode. Nature 2006, 442, 291-294. [CrossRef] [PubMed]

59. Yirgu, G.; Ababa, A.; Ayele, A. Recent seismovolcanic crisis in northern Afar, Ethiopia. Eos, Trans. Am. Geophys. Union 2006, 87, 325-329. [CrossRef]

(C) 2015 by the authors; licensee MDPI, Basel, Switzerland. This article is an open access article distributed under the terms and conditions of the Creative Commons by Attribution (CC-BY) license (http://creativecommons.org/licenses/by/4.0/). 